\title{
Effect of Sex and Seasonal Changes on New Zealand Rabbit Fur under Egyptian Semi-Arid Conditions
}

\author{
Taha E.A., Nasr A.I., Essa D.G., Kassem S.T., El-Shemy K.A.
}

Department of Wool Production \& Technology, Animal \& Poultry Production Division Desert Research Centre, Cairo, Egypt Correspondence: Taha, E.A.

\begin{abstract}
This study aimed to evaluate the effect of season and sex on New Zealand White rabbits' fur under Egyptian semi-arid conditions. A total of 40 rabbits (20 males and 20 females) aged 3.5 to 4 months were used during two subsequent seasons; summer and winter (20 rabbits in each season). Skin samples were taken pre-slaughtering to determine the histological and histochemical parameters and skin layer thicknesses. After slaughtering and chrome tanning of skinned furs, the mechanical and chemical properties were determined on the chrome tanned furs. The current study was detected variations in the skin characteristics and tanned fur properties due to both season and sex. The summer and females skins were thicker in papillary layer vs. reticular layer than winter and males skins to accommodate the increment of the follicle activity. Additionally, the skins' follicles of both summer and females skins were denser and smaller which produced finer fibers with lower homogeneity than those of the corresponding winter and males ones, respectively. Therefore, both summer and female tanned furs were the lower quality due to the decrement in reticular layer thickness and increment of follicle density. The study concluded that all skins had most fibers $<30 \mu \mathrm{m}$ and thus their furs are suitable for using without causing irritation to humans when worn next to the skin. Also, the tanned furs could be used in garment leather manufacturing after reinforcing with textile padding.
\end{abstract}

Keywords - chrome tanning, collagen fiber, histochemistry, histology, mechanical properties.

\section{INTRODUCTION}

High quality rabbit skins are used in fur garments, trimming, in medical and cosmetics researches [1]. New Zealand White (NZW) rabbits are from the most popular meat producers and pet strain in the world [2]. According to FAO (2018), Egypt is the third top producer for rabbit meat. The live numbers of rabbits were determined as about 6.5 million heads, whereas the slaughtered numbers were about 55 million heads [3]. Although NZW rabbits are considered one of the major rabbit breeds in Egypt [4], but still the intensive meat rabbit production techniques are usually incompatible with production standards for quality fur pelts [5]. Additionally to the animal breed, there are various factors that affect the characteristics of animals' skins such as sex, seasonal variations, production system and slaughtering age $[1,5,6]$. Therefore, the raw rabbits' furs represent a small value of the living animals and can only constitute a by-product [5].
Though some previous investigations have indicated several factors that affect the properties of rabbits' furs, there is still a lack of researches on evaluating changes in the rabbit's coat under Egyptian conditions.

Therefore, this study aimed at investigating the effect of sex and seasonal changes on NZW rabbit fur characteristics, including the parameters of coat fiber homogeneity, histological constructions, histochemical traits and skin layers thicknesses as well as, the compatibility of tanned fur for leather manufacturing purposes.

\section{MATERIALS AND METHODS}

\subsection{Study location:}

The study was carried out at Maryout Research Station, Desert Research Centre, which located at $35 \mathrm{~km}$ South West of Alexandria ( $\left.31^{\circ} 00^{\prime} 22.2^{\prime \prime} \mathrm{N}, 29^{\circ} 47^{\prime} 24.0^{\prime \prime} \mathrm{E}\right)$. 


\subsection{Animals and management:}

This study was approved by the Animal Ethics Committee of Animal and Poultry Production Division, Desert Research Centre. A total of 40 NZW rabbits (20 males and 20 females) aged 3.5 to 4 months were used during two subsequent seasons; summer and winter (20 rabbits in each season representing different genders). The animals were housed in a building with high clear glass windows and kept under properly controlled air ventilation. Therefore, animals were housed under natural lighting, and were protected from strong air currents. Ambient temperatures inside the building ranged from 23 to $30^{\circ} \mathrm{C}$ in summer (June to August), and from 12 to $20^{\circ} \mathrm{C}$ in winter (December to February). Animals were individually housed in metal wire cages and maintained under the same management program. Rabbits were fed on a commercial diet $(15.8 \%$ crude protein, $19.3 \%$ acid detergent fiber, 9.8 MJ digestible energy/kg as-fed bases) during the entire experiment. No antibiotics were added to feed or water.

\subsection{Determination of fur fiber physical traits:}

At slaughtering time, rabbits' body weight (g) was recorded and a small snippet of the hair fibers was taken by a sharp clipper from the right flank region of each rabbit to assess the physical traits of fur fibers [7]. Average fiber diameter (FD) was measured by using Carl-Zeiss micro image analyzer (Zen, Blue edition). Five hundred hair fiber samples were randomly collected to determine the length and type of fibers [8]. The standard deviation of fiber diameter (SDFD) and the standard deviation of fiber length (SDFL) were used to express the uniformity of both traits; where the higher estimates of standard deviation referred to less uniformity in the normal distribution of the values around the mean value and vice versa [9].

\subsection{Histological parameters determination:}

A skin biopsy sample was taken from the same region of fur sampling by a curved scissor for histological determinations. Skin specimens were fixed on foam to get flattened then fixation was performed in calcium formol [10]. Skin specimens were then dehydrated in an ascending series of ethanol, cleared in benzene, infiltrated in paraffin wax and then embedded in the same paraffin to prepare the blocks. Then it was sliced to cross and vertical sections that were stained by Haematoxylin and Eosin stain to conduct the histological examinations [11]. Histochemical demonstration of general carbohydrates was performed by Periodic Acid Schiff's (PAS) reaction, while Mercury Bromophenol blue was used for the demonstration of general proteins [12].

Histological and histochemical parameters were measured using Image analyzer software (Zen, Blue edition) and ISSN: 2456-1878 device Carl-Zeiss micro-imaging (lenses 10/0.847 and 40/ $0,65)$.

\subsection{Fur tanning and testing:}

After slaughtering, skin weight was determined, thereafter, skin was chrome tanned [6] then mechanical and chemical properties of tanned furs were determined according to standard procedures of ASTM [13]. Examined mechanical properties were; fur thickness, fur area, tensile strength, elongation percentage at break and split tear strength, while chemical properties were moisture, chromic oxide and $\mathrm{pH}$.

\subsection{Statistical analysis:}

Data were analyzed with SAS [14] program using general linear model (GLM) procedure for analysis of variance. Means were significantly separated using Duncan's multiple range tests.

The fixed effect model used was:

$$
Y_{i j k}=\mu+N_{i}+B_{j}+N_{i j}+e_{i j k}
$$

Where $Y_{i j k}$ is the observation taken $(k), \mu$ is an overall mean, $N_{i}$ is a fixed effect of the (i) Season (Summer and Winter), $B_{j}$ a fixed effect of the (j) sex (Male and Female), $\mathrm{NB}_{\mathrm{ij}}$ is an interaction effect between season and sex, and $\mathrm{e}_{\mathrm{ijk}}$ is a random error assumed to be normally distributed with mean $=0$ and variance $=\sigma^{2} e$.

\section{RESULTS AND DISCUSSIONS}

\subsection{Histological parameters:}

Tables (1) and (2) show the dimensions of primary and secondary follicles, respectively whereas, Fig (1) shows the transvers sections of NZW skin of primary and secondary follicles for the two sexes at different seasons. Additionally, the $\mathrm{s} / \mathrm{p}$ ratio and follicle density data are presented in Table (3).

Except the sex effect on wall thickness of primary follicle, the significant $(\mathrm{P}<0.01)$ effects of sex, season and their interaction were found with the two types of follicles for all histological characteristics (Tables 1 and 2). Also, follicle density was affected significantly $(\mathrm{P}<0.01)$ by season, sex and their interaction, while season effect did not affect the s/p ratio (Table 3).

At the two seasons, all primary and secondary follicles of male skins had larger external diameter than female skins (Fig 1). This result may explain the decrement of follicle density in male skins. In some previous investigations, the fiber density was significantly higher in female rabbits than that of the male rabbits as found in this study [2, 8], while the insignificant difference between the two sexes was revealed by another study [15]. 
Because of higher $\mathrm{s} / \mathrm{p}$ ratio in summer skins which had the smaller secondary follicles, the summer skins were denser follicles than corresponding winter skins as coincided with our previous work [16].

Regarding to the histological fiber diameter, the primary follicles of female skins produced fibers finer than those produced from male skins at the two seasons, as well as, the fibers produced at winter season were finer than those produced at summer winter. However, the behavior of the secondary follicles was differed from that of the primary follicles. The finer fibers were produced at summer season from male skins, while it produced at winter season from female skins. [16].

Table 1: Least square means \pm standard error of primary follicle diameters $(\mu m)$ for New Zealand White (NZW) as affected by season, sex and their interaction.

\begin{tabular}{|c|c|c|c|c|c|}
\hline \multicolumn{2}{|c|}{ Parameter } & External diameter & Internal diameter & Wall thickness & Fiber diameter \\
\hline \multicolumn{2}{|c|}{ Season effect $(\mathrm{N})$} & $* *$ & $* *$ & $*$ & $* *$ \\
\hline \multicolumn{2}{|l|}{ Summer } & $137.73 \pm 6.59$ & $72.44 \pm 4.05$ & $65.29 \pm 3.93$ & $52.30 \pm 3.74$ \\
\hline \multicolumn{2}{|l|}{ Winter } & $110.70 \pm 5.31$ & $56.10 \pm 3.26$ & $54.61 \pm 3.16$ & $42.75 \pm 3.02$ \\
\hline \multicolumn{2}{|c|}{ Sex effect (B) } & $* *$ & $* *$ & ns & $* *$ \\
\hline \multicolumn{2}{|l|}{ Male } & $135.51 \pm 5.82$ & $73.05 \pm 3.52$ & $62.45 \pm 3.50$ & $55.42 \pm 3.33$ \\
\hline \multicolumn{2}{|l|}{ Female } & $107.18 \pm 5.82$ & $52.01 \pm 3.52$ & $55.17 \pm 3.50$ & $41.53 \pm 3.33$ \\
\hline \multicolumn{2}{|c|}{ Interaction effect $(\mathrm{N} \times \mathrm{B})$} & $* *$ & $* *$ & $* *$ & $* *$ \\
\hline \multirow{2}{*}{ Summer } & Male & $163.75 \pm 8.54^{\mathrm{a}}$ & $87.01 \pm 5.25^{\mathrm{a}}$ & $76.73 \pm 5.21^{\mathrm{a}}$ & $67.57 \pm 4.98^{\mathrm{a}}$ \\
\hline & Female & $107.12 \pm 9.27^{b}$ & $55.30 \pm 5.70^{\mathrm{b}}$ & $51.82 \pm 5.65^{\mathrm{b}}$ & $45.21 \pm 5.40^{\mathrm{b}}$ \\
\hline \multirow{2}{*}{ Winter } & Male & $114.59 \pm 7.35^{b}$ & $62.71 \pm 4.52^{b}$ & $51.87 \pm 4.49^{\mathrm{b}}$ & $46.42 \pm 4.28^{b}$ \\
\hline & Female & $107.21 \pm 6.98^{b}$ & $50.14 \pm 4.29^{b}$ & $57.07 \pm 4.25^{\mathrm{b}}$ & $39.44 \pm 4.06^{\mathrm{b}}$ \\
\hline
\end{tabular}

ns: non-significance, $* \mathrm{P}<0.05, * * \mathrm{P}<0.01$

Means in the same column of group having different superscripts are significantly different $(\mathrm{P}<0.05)$.

Table 2: Least square means \pm standard error of secondary follicle diameters $(\mu \mathrm{m})$ for New Zealand White (NZW) as affected by season, sex and their interaction.

\begin{tabular}{|c|c|c|c|c|c|}
\hline \multicolumn{2}{|c|}{ Parameter } & External diameter & Internal diameter & Wall thickness & Fiber diameter \\
\hline \multicolumn{2}{|c|}{ Season effect $(\mathrm{N})$} & $* *$ & $* *$ & $* *$ & $* *$ \\
\hline \multicolumn{2}{|l|}{ Summer } & $29.82 \pm 2.48$ & $11.63 \pm 0.97$ & $18.19 \pm 1.96$ & $7.17 \pm 0.60$ \\
\hline \multicolumn{2}{|l|}{ Winter } & $43.64 \pm 2.12$ & $16.51 \pm 0.83$ & $27.13 \pm 1.67$ & $9.78 \pm 0.51$ \\
\hline \multicolumn{2}{|c|}{ Sex effect (B) } & $* *$ & $* *$ & $* *$ & $* *$ \\
\hline \multicolumn{2}{|l|}{ Male } & $45.49 \pm 2.32$ & $17.87 \pm 0.89$ & $27.62 \pm 1.86$ & $10.50 \pm 0.55$ \\
\hline \multicolumn{2}{|l|}{ Female } & $30.92 \pm 2.21$ & $11.38 \pm 0.84$ & $19.54 \pm 1.76$ & $7.04 \pm 0.53$ \\
\hline \multicolumn{2}{|c|}{ Interaction effect $(\mathrm{N} \times \mathrm{B})$} & $* *$ & $* *$ & $* *$ & $* *$ \\
\hline \multirow{2}{*}{ Summer } & Male & $30.94 \pm 3.19^{b}$ & $10.87 \pm 1.14^{\mathrm{b}}$ & $20.07 \pm 2.68^{\mathrm{b}}$ & $6.02 \pm 0.70^{c}$ \\
\hline & Female & $28.70 \pm 3.19^{b}$ & $12.40 \pm 1.14^{\mathrm{b}}$ & $16.30 \pm 2.68^{\mathrm{b}}$ & $8.32 \pm 0.70^{b}$ \\
\hline \multirow{2}{*}{ Winter } & Male & $57.12 \pm 2.86^{\mathrm{a}}$ & $23.47 \pm 1.02^{\mathrm{a}}$ & $33.66 \pm 2.40^{\mathrm{a}}$ & $14.08 \pm 0.63^{\mathrm{a}}$ \\
\hline & Female & $32.40 \pm 2.61^{\mathrm{b}}$ & $10.71 \pm 0.93^{b}$ & $21.69 \pm 2.19^{b}$ & $6.20 \pm 0.57^{c}$ \\
\hline
\end{tabular}

$* * \mathrm{P}<0.01$

Means in the same column of group having different superscripts are significantly different $(\mathrm{P}<0.05)$. 


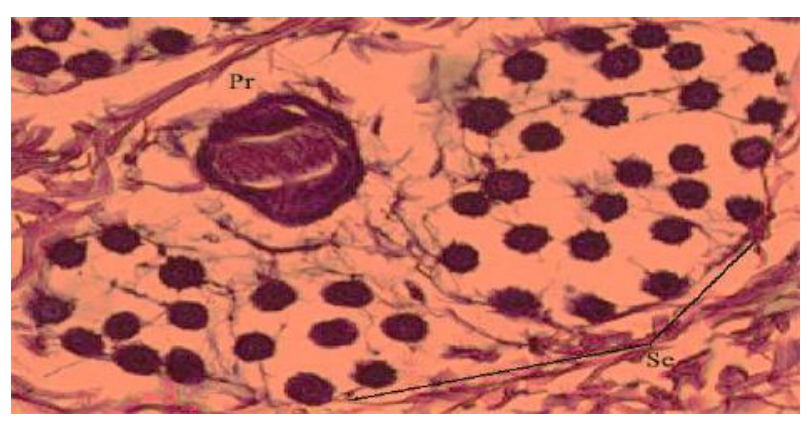

NZW female at summer

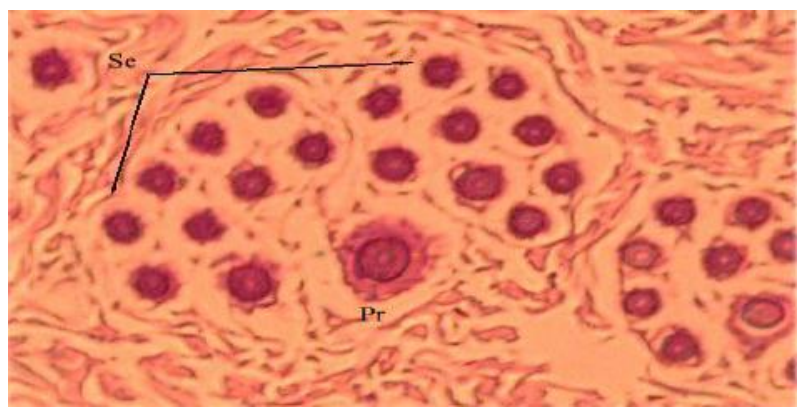

NZW male at summer

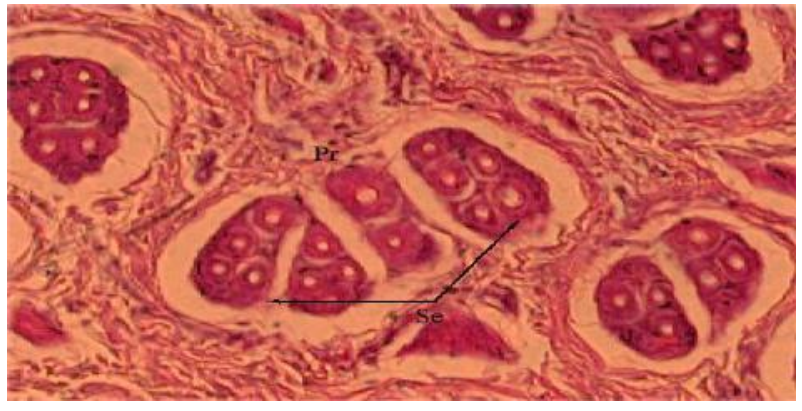

NZW female at winter

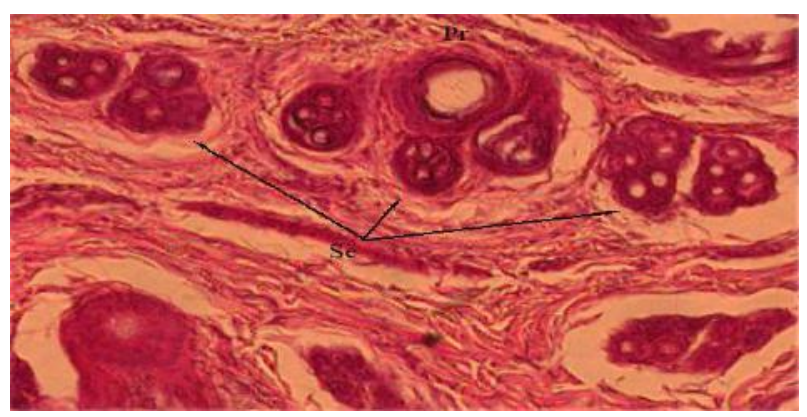

NZW male at winter

Fig. 1: Transverse section of New Zealand rabbit (NZW) skin showing primary follicles (Pr) and secondary follicles (Se) for both sexes at different seasons. (Hx\&E.,x100)

Table 3: Least square means \pm standard error of S/P ratio and follicle density (follicle/mm ${ }^{2}$ ) for New Zealand White (NZW) as affected by season, sex and their interaction.

\begin{tabular}{|c|c|c|c|}
\hline \multicolumn{2}{|c|}{ Parameter } & $\mathrm{S} / \mathrm{P}$ ratio & Follicle density \\
\hline \multicolumn{2}{|c|}{ Season effect (N) } & ns & $* *$ \\
\hline \multicolumn{2}{|l|}{ Summer } & $19.03 \pm 1.22$ & $198.02 \pm 4.50$ \\
\hline \multicolumn{2}{|l|}{ Winter } & $16.50 \pm 1.31$ & $167.19 \pm 5.14$ \\
\hline \multicolumn{2}{|c|}{ Sex effect (B) } & $* *$ & $* *$ \\
\hline \multicolumn{2}{|l|}{ Male } & $12.34 \pm 1.26$ & $169.06 \pm 5.63$ \\
\hline \multicolumn{2}{|l|}{ Female } & $21.50 \pm 1.03$ & $193.21 \pm 4.80$ \\
\hline \multicolumn{2}{|c|}{ Interaction effect $(\mathrm{N} \times \mathrm{B})$} & $* *$ & $* *$ \\
\hline \multirow{2}{*}{ Summer } & Male & $11.60 \pm 1.48^{\mathrm{c}}$ & $173.09 \pm 7.58^{\mathrm{b}}$ \\
\hline & Female & $25.79 \pm 1.41^{\mathrm{a}}$ & $214.64 \pm 6.19^{\mathrm{a}}$ \\
\hline \multirow{2}{*}{ Winter } & Male & $13.67 \pm 1.97^{\mathrm{bc}}$ & $165.23 \pm 7.38^{\mathrm{b}}$ \\
\hline & Female & $17.77 \pm 1.32^{\mathrm{b}}$ & $168.77 \pm 6.60^{\mathrm{b}}$ \\
\hline
\end{tabular}

$\mathrm{S} / \mathrm{P}$ ratio = secondary follicle numbers / primary follicle numbers

ns: non-significance, $* * \mathrm{P}<0.01$

Means in the same column of group having different superscripts are significantly different $(\mathrm{P}<0.05)$.

The negative and high correlation between histological fiber diameter and follicle density was pointed out in a previous investigation [17]. Therefore, it could be concluded that the follicles of males or winter skins tended to be lower density and larger dimensions, which produced coarser fibers than females or summer skins respectively, which coincided with aforementioned investigation [18, 19]. 
Figure (2) and Table (4) show the skin layer thicknesses of the studied NZW rabbits. Although the effects of season and sex were not uniform on all skin layers with exception of hypodermis layer, all skin layers were highly significant affected by the effect of interaction between season and sex.

Realistically, dermis layer, which consists of papillary and reticular layers, is the most interest layer in the skin and thus it called the real skin $[6,20,21]$. Therefore, data

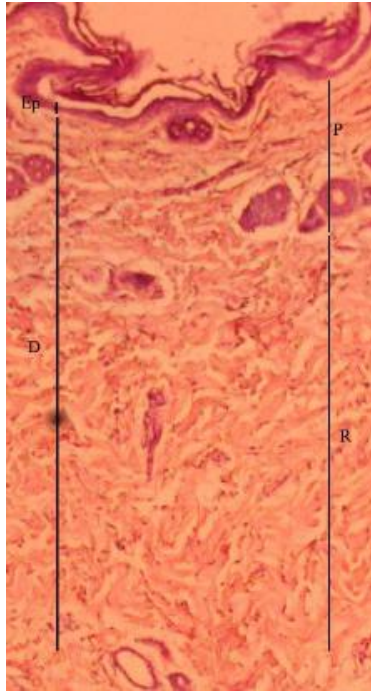

Male summer

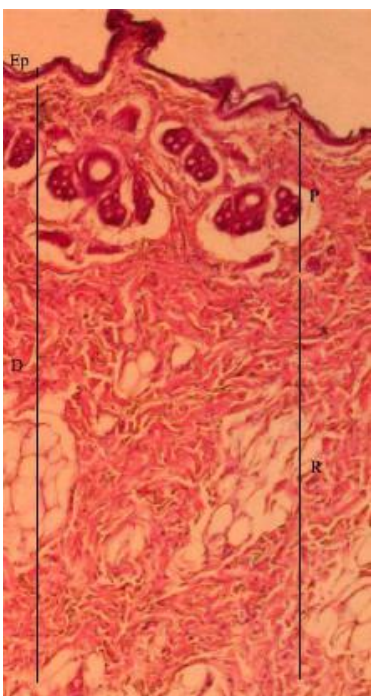

Male winter

exhibited that at both seasons, male skins had thicker papillary and reticular layers than female skins. This result is in coincidence partially with a previous study, which illustrated the thicker papillary layer in female skins and the thicker reticular layer in male skins [15].

Moreover, in papillary layer, summer skins were thicker than winter skins at the two sexes, while the opposite was found in reticular layer, which in agreement with our previous work [16].

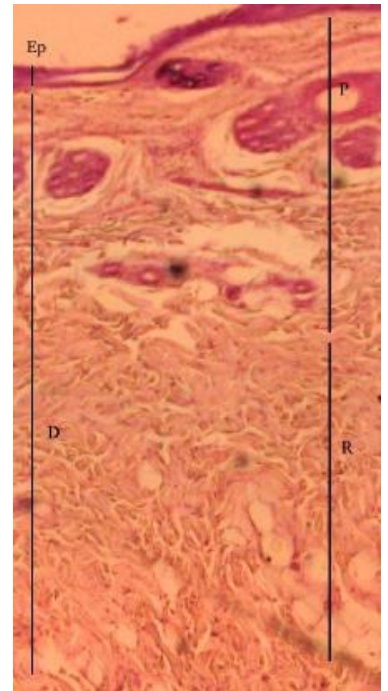

Female summer

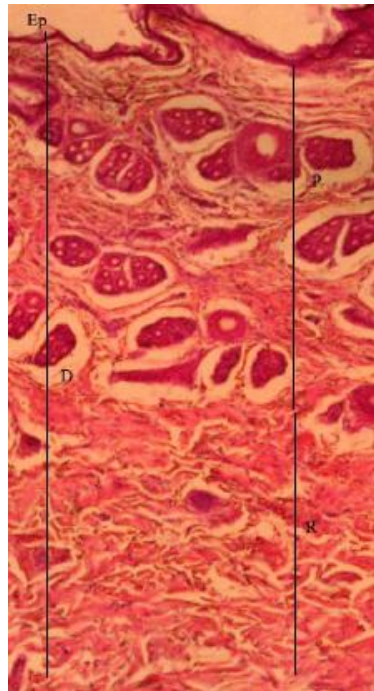

Female winter

Fig. 2: Vertical sections of New Zealand rabbit (NZW) skin for both sexes at different seasons show different skin layers, dermis $(D)$, epidermis $(E p)$, papillary $(P)$, reticular $(R) .(H x \& E ., x 50)$.

Table 4: Least square means \pm standard error of skin layers thickness $(\mu \mathrm{m})$ for New Zealand White (NZW) as affected by season, sex and their interaction.

\begin{tabular}{|c|c|c|c|c|c|}
\hline \multicolumn{2}{|c|}{ Parameter } & Epidermis & Papillary & Reticular & Hypodermis \\
\hline \multicolumn{2}{|c|}{ Season effect $(\mathrm{N})$} & ns & $* *$ & $* *$ & ns \\
\hline \multicolumn{2}{|l|}{ Summer } & $19.05 \pm 1.18$ & $1266.73 \pm 81.16$ & $624.23 \pm 39.26$ & $406.71 \pm 38.93$ \\
\hline \multicolumn{2}{|l|}{ Winter } & $19.13 \pm 1.18$ & $818.20 \pm 81.16$ & $797.94 \pm 39.26$ & $452.55 \pm 35.54$ \\
\hline \multicolumn{2}{|c|}{ Sex effect (B) } & ns & $* *$ & ns & ns \\
\hline \multicolumn{2}{|l|}{ Male } & $20.13 \pm 1.17$ & $1238.95 \pm 82.37$ & $761.54 \pm 40.32$ & $382.81 \pm 38.55$ \\
\hline \multicolumn{2}{|l|}{ Female } & $18.05 \pm 1.17$ & $845.99 \pm 82.37$ & $660.62 \pm 40.32$ & $472.47 \pm 35.19$ \\
\hline \multicolumn{2}{|c|}{ Interaction effect $(\mathrm{N} \times \mathrm{B})$} & $* *$ & $* *$ & $* *$ & ns \\
\hline \multirow{2}{*}{ Summer } & Male & $25.61 \pm 1.32^{\mathrm{a}}$ & $1403.64 \pm 109.31^{\mathrm{a}}$ & $724.06 \pm 54.44^{\mathrm{a}}$ & $380.05 \pm 60.98$ \\
\hline & Female & $12.49 \pm 1.32^{b}$ & $1129.82 \pm 109.31^{\mathrm{ab}}$ & $524.39 \pm 54.44^{b}$ & $424.48 \pm 49.79$ \\
\hline \multirow{2}{*}{ Winter } & Male & $14.64 \pm 1.32^{\mathrm{b}}$ & $1074.25 \pm 109.31^{\mathrm{b}}$ & $799.02 \pm 54.44^{\mathrm{a}}$ & $384.66 \pm 49.79$ \\
\hline & Female & $23.62 \pm 1.32^{\mathrm{a}}$ & $562.16 \pm 109.31^{\mathrm{c}}$ & $796.85 \pm 54.44^{\mathrm{a}}$ & $520.45 \pm 49.79$ \\
\hline
\end{tabular}

ns: non-significance, $* * \mathrm{P}<0.01$

Means in the same column of group having different superscripts are significantly different $(\mathrm{P}<0.05)$. 


\subsection{Histochemical parameters:}

The distribution of general proteins and carbohydrates in different root sheath of primary and secondary follicles are demonstrated in Fig (3), while the optical density values are presented in Tables (5) and (6). The optical density values of carbohydrates and proteins for the outer and inner sheaths of both primary and secondary follicles were highly significant affected by the interaction effect between season and sex.

Proteins histochemical reaction showed that summer skins had higher optical density than corresponding skins of winter for both sexes. Also, male skins were higher than female skins in the optical density values of proteins.

In other regard, the trends between the two sexes at the two seasons were different in carbohydrates histochemical

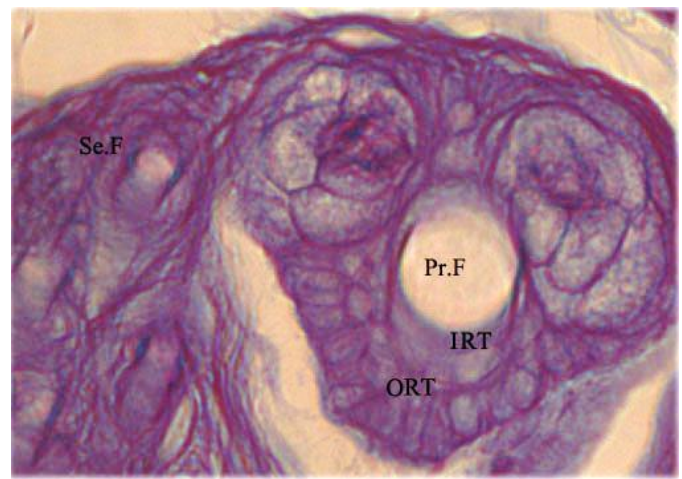

Protein (Bromo-phenol blue, $x 400$ ) reaction. The optical density values for all male skins follicles were higher at winter season than summer season, whereas the opposite trend was found with female skins. Thus, the female skins were significantly $(\mathrm{P}<0.01)$ higher than male ones in optical density of carbohydrates.

The previous investigations indicated that carbohydrates in the root sheaths are a source of energy for protein synthesis during fiber growth [22 - 24], as well as, the higher protein content in active follicle sheaths are associated with an increased protein synthesis during the cellular proliferation [25].

Therefore, in general, these results gave an indication of an increased follicles activity during the summer season than in the winter season, as well as in female skins more than male skins.

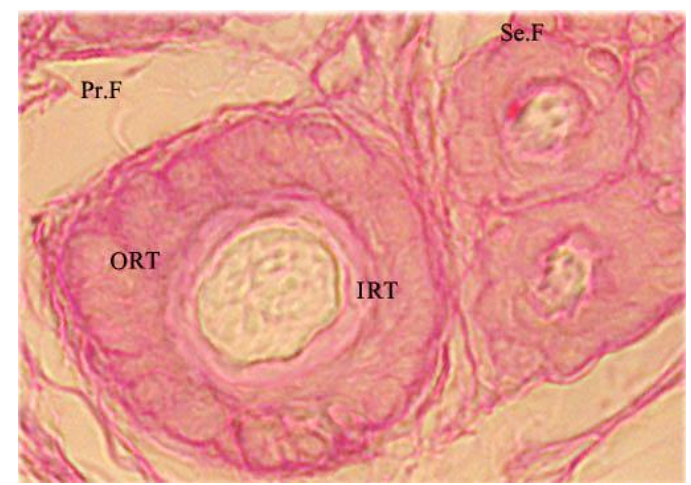

Carbohydrates (PAS, x400)

Fig. 3: Transverse section of NZW skin showing the distribution of general protein and carbohydrates in different follicle structures. Inner root sheath (IRT), outer root sheath (ORT), primary follicles (Pr.F) and secondary follicles (Se.F).

\subsection{Fur fiber physical traits:}

Table (7) shows the fur fiber physical traits of studied NZW rabbits as affected by sex, season and their interactions. Regarding to the interaction effect between sex and season, fiber diameter homogeneity of NZW furs was significantly $(\mathrm{P}<0.05)$ affected, whereas other fur fiber physical traits did not affect. Nevertheless, the hair fibers of both winter and male furs tended to be finest, shortest and more homogenous.

At the growing Rex and NZW rabbits, the hair of male rabbits is insignificantly thicker and longer than that of female ones [8], which are in contrast with the current result.

Because of the effect of season on histological and histochemical parameters as observed in the aforementioned results, these changes in fur fiber physical traits may be due to the seasonal changes in follicle activity that affect the rate of cell proliferation during the fiber development process to cause fluctuations in skin follicle dimensions and change the growth rate of the follicular cell layers and the activity of the germinal matrix to proliferate and elongate coat fibers [2, 26, 27].

On the other hand, both of male and female skins at the two different seasons had average fiber diameters less than $30 \mu \mathrm{m}$. That gives an indication of lower prickling feeling and indicates to the suitability of using NZW rabbit furs without causing irritation to humans when worn adjacent to human skin [15]. 
Table 5: Least square means \pm standard error of optical density (O.D.) values of general proteins reactions for New Zealand White (NZW) as affected by season, sex and their interaction.

\begin{tabular}{|c|c|c|c|c|c|}
\hline \multirow{2}{*}{\multicolumn{2}{|c|}{ Parameter }} & \multicolumn{2}{|c|}{ Primary follicle } & \multicolumn{2}{|c|}{ Secondary follicle } \\
\hline & & Outer root sheath & Inner root sheath & Outer root sheath & Inner root sheath \\
\hline \multicolumn{2}{|c|}{ Season effect $(\mathrm{N})$} & $* *$ & $* *$ & $* *$ & *** \\
\hline \multicolumn{2}{|l|}{ Summer } & $0.527 \pm 0.007$ & $0.472 \pm 0.005$ & $0.615 \pm 0.005$ & $0.468 \pm 0.004$ \\
\hline \multicolumn{2}{|l|}{ Winter } & $0.482 \pm 0.006$ & $0.447 \pm 0.004$ & $0.537 \pm 0.005$ & $0.435 \pm 0.004$ \\
\hline \multicolumn{2}{|c|}{ Sex effect (B) } & $*$ & $* *$ & $* *$ & $* *$ \\
\hline \multicolumn{2}{|l|}{ Male } & $0.511 \pm 0.007$ & $0.476 \pm 0.005$ & $0.588 \pm 0.006$ & $0.493 \pm 0.004$ \\
\hline \multicolumn{2}{|l|}{ Female } & $0.492 \pm 0.006$ & $0.442 \pm 0.005$ & $0.557 \pm 0.005$ & $0.418 \pm 0.004$ \\
\hline \multicolumn{2}{|c|}{ Interaction effect $(\mathrm{N} \times \mathrm{B})$} & $* *$ & $* *$ & $* *$ & $* *$ \\
\hline \multirow{2}{*}{ Summer } & Male & $0.536 \pm 0.010^{\mathrm{a}}$ & $0.455 \pm 0.008^{\mathrm{b}}$ & $0.606 \pm 0.008^{\mathrm{a}}$ & $0.492 \pm 0.006^{\mathrm{a}}$ \\
\hline & Female & $0.519 \pm 0.010^{\mathrm{a}}$ & $0.487 \pm 0.007^{\mathrm{a}}$ & $0.623 \pm 0.008^{\mathrm{a}}$ & $0.449 \pm 0.006^{\mathrm{b}}$ \\
\hline \multirow{2}{*}{ Winter } & Male & $0.491 \pm 0.009^{b}$ & $0.492 \pm 0.007^{\mathrm{a}}$ & $0.571 \pm 0.008^{b}$ & $0.494 \pm 0.006^{\mathrm{a}}$ \\
\hline & Female & $0.475 \pm 0.007^{b}$ & $0.415 \pm 0.006^{c}$ & $0.514 \pm 0.006^{\mathrm{c}}$ & $0.399 \pm 0.005^{\mathrm{c}}$ \\
\hline
\end{tabular}

$* \mathrm{P}<0.05, * * \mathrm{P}<0.01$

Means in the same column of group having different superscripts are significantly different $(\mathrm{P}<0.05)$.

Table 6: Least square means \pm standard error of optical density (O.D.) values of general carbohydrates reactions for New Zealand White (NZW) as affected by season, sex and their interaction.

\begin{tabular}{|c|c|c|c|c|c|}
\hline \multirow{2}{*}{\multicolumn{2}{|c|}{ Parameter }} & \multicolumn{2}{|c|}{ Primary follicle } & \multicolumn{2}{|c|}{ Secondary follicle } \\
\hline & & Outer root sheath & Inner root sheath & Outer root sheath & Inner root sheath \\
\hline \multicolumn{2}{|c|}{ Season effect $(\mathrm{N})$} & ns & ns & $* *$ & ns \\
\hline \multicolumn{2}{|l|}{ Summer } & $0.385 \pm 0.002$ & $0.372 \pm 0.002$ & $0.400 \pm 0.002$ & $0.355 \pm 0.002$ \\
\hline \multicolumn{2}{|l|}{ Winter } & $0.382 \pm 0.002$ & $0.376 \pm 0.002$ & $0.388 \pm 0.002$ & $0.354 \pm 0.002$ \\
\hline \multicolumn{2}{|c|}{ Sex effect (B) } & $* *$ & $* *$ & $* *$ & $* *$ \\
\hline \multicolumn{2}{|l|}{ Male } & $0.378 \pm 0.003$ & $0.362 \pm 0.003$ & $0.382 \pm 0.003$ & $0.347 \pm 0.002$ \\
\hline \multicolumn{2}{|l|}{ Female } & $0.387 \pm 0.002$ & $0.381 \pm 0.002$ & $0.401 \pm 0.002$ & $0.359 \pm 0.002$ \\
\hline \multicolumn{2}{|c|}{ Interaction effect $(\mathrm{N} \times \mathrm{B})$} & $* *$ & $* *$ & $* *$ & $* *$ \\
\hline \multirow{2}{*}{ Summer } & Male & $0.348 \pm 0.004^{c}$ & $0.333 \pm 0.004^{c}$ & $0.379 \pm 0.004^{c}$ & $0.332 \pm 0.003^{\mathrm{d}}$ \\
\hline & Female & $0.403 \pm 0.003^{\mathrm{a}}$ & $0.391 \pm 0.003^{\mathrm{a}}$ & $0.414 \pm 0.003^{\mathrm{a}}$ & $0.369 \pm 0.002^{\mathrm{a}}$ \\
\hline \multirow{2}{*}{ Winter } & Male & $0.398 \pm 0.003^{\mathrm{a}}$ & $0.383 \pm 0.003^{\mathrm{a}}$ & $0.385 \pm 0.003^{b c}$ & $0.359 \pm 0.002^{b}$ \\
\hline & Female & $0.370 \pm 0.003^{\mathrm{b}}$ & $0.371 \pm 0.003^{b}$ & $0.390 \pm 0.003^{b}$ & $0.350 \pm 0.002^{c}$ \\
\hline
\end{tabular}

ns: non-significance, $* * \mathrm{P}<0.01$

Means in the same column of group having different superscripts are significantly different $(\mathrm{P}<0.05)$. 
Table 7: Least square means \pm standard error of fur fiber physical traits for New Zealand White (NZW) as affected by season, sex and their interaction.

\begin{tabular}{|c|c|c|c|c|c|}
\hline \multicolumn{2}{|c|}{ Parameter } & $\mathrm{FD}(\mu \mathrm{m})$ & SDFD & FL $(\mathrm{cm})$ & SDFL \\
\hline \multicolumn{2}{|c|}{ Season effect (N) } & $\mathrm{ns}$ & $*$ & * & * \\
\hline \multicolumn{2}{|l|}{ Summer } & $19.98 \pm 0.490$ & $11.56 \pm 0.917$ & $3.77 \pm 0.118$ & $0.513 \pm 0.022$ \\
\hline \multicolumn{2}{|l|}{ Winter } & $17.75 \pm 0.419$ & $7.24 \pm 0.785$ & $3.36 \pm 0.101$ & $0.442 \pm 0.019$ \\
\hline \multicolumn{2}{|c|}{ Sex effect (B) } & ns & ns & ns & ns \\
\hline \multicolumn{2}{|l|}{ Male } & $18.01 \pm 0.459$ & $8.77 \pm 1.003$ & $3.46 \pm 0.116$ & $0.46 \pm 0.022$ \\
\hline \multicolumn{2}{|l|}{ Female } & $18.57 \pm 0.496$ & $9.43 \pm 1.083$ & $3.61 \pm 0.126$ & $0.48 \pm 0.023$ \\
\hline \multicolumn{2}{|c|}{ Interaction effect $(\mathrm{N} \times \mathrm{B})$} & ns & $*$ & ns & ns \\
\hline \multirow{2}{*}{ Summer } & Male & $18.71 \pm 0.681$ & $10.48 \pm 1.248^{\mathrm{ab}}$ & $3.67 \pm 0.163$ & $0.48 \pm 0.031$ \\
\hline & Female & $19.31 \pm 0.746$ & $12.87 \pm 1.367^{\mathrm{a}}$ & $3.88 \pm 0.179$ & $0.54 \pm 0.034$ \\
\hline \multirow{2}{*}{ Winter } & Male & $17.49 \pm 0.590$ & $7.48 \pm 1.081^{\mathrm{b}}$ & $3.31 \pm 0.141$ & $0.44 \pm 0.026$ \\
\hline & Female & $18.05 \pm 0.631$ & $6.97 \pm 1.155^{\mathrm{b}}$ & $3.42 \pm 0.151$ & $0.44 \pm 0.028$ \\
\hline
\end{tabular}

ns: non-significance, $* \mathrm{P}<0.05$

FD: fibre diameter, SDFD: standard deviation of fibre diameter, FL: fibre length, SDFL: standard deviation of fibre length.

Means in the same column of group having different superscripts are significantly different $(\mathrm{P}<0.05)$.

\subsection{Tanned fur properties:}

No effects for season, sex and their interaction on animal weight, skin weight and fur's area and thickness (Table 8). This similarity among animals in these parameters may return to the limited changes between animals before the age of sexual maturity [5].

The mechanical and chemical properties for the furs of experimental animals are presented in Table (9). The chemical properties were not differed among studied groups and not affected by season, sex and their interaction, which may attributable to the similarity in tanning steps and processes done on all rabbit skins [6]. Meanwhile, the chemical properties values were within an acceptable range for using it in different manufacturing processes [28].
With respect to mechanical properties, the interaction effect between season and sex did not affect the quality of tanned furs. Nevertheless, the furs from male animals were significantly $(\mathrm{P}<0.05)$ higher in tensile strength and elongation than furs from female animals (141.07 \pm 2.67 $\mathrm{kg} / \mathrm{cm}^{2}$ vs. $131.09 \pm 2.87 \mathrm{~kg} / \mathrm{cm}^{2}$ and $45.86 \pm 1.28 \%$ vs. $42.01 \pm 1.37 \%$, respectively). Additionally, the tanned furs from summer season were significantly $(\mathrm{P}<0.01)$ higher than corresponding tanned furs from winter season in tearing strength $(25.93 \pm 1.24 \mathrm{~kg} / \mathrm{cm}$ vs. $21.29 \pm 1.07 \mathrm{~kg} / \mathrm{cm}$, respectively) but the opposite was found with tensile strength and elongation properties with insignificant differences. Thus, data revealed that the tanned furs tended to be more durable in male rabbits than in female rabbits, as well as the tanned furs from winter season are higher quality than those obtained from summer season. 
International Journal of Environment, Agriculture and Biotechnology, 5(3)

May-Jun, 2020 / Available: https://ijeab.com/

Table 8: Least square means \pm standard error of animal weight, skin weight, fur area and fur thickness for New Zealand White (NZW) as affected by season, sex and their interaction.

\begin{tabular}{|c|c|c|c|c|c|}
\hline \multicolumn{2}{|c|}{ Parameter } & Animal weight (gm) & Skin weight (gm) & Fur area $\left(\mathrm{cm}^{2}\right)$ & Fur thickness (mm) \\
\hline \multicolumn{2}{|c|}{ Season effect $(\mathrm{N})$} & ns & ns & ns & ns \\
\hline \multicolumn{2}{|l|}{ Summer } & $2075.00 \pm 85.77$ & $194.58 \pm 11.22$ & $1130.50 \pm 46.78$ & $0.90 \pm 0.02$ \\
\hline \multicolumn{2}{|l|}{ Winter } & $1912.50 \pm 74.28$ & $189.63 \pm 9.72$ & $1114.35 \pm 40.51$ & $0.91 \pm 0.02$ \\
\hline \multicolumn{2}{|c|}{ Sex effect (B) } & ns & ns & ns & ns \\
\hline \multicolumn{2}{|l|}{ Male } & $1966.67 \pm 79.56$ & $194.93 \pm 10.02$ & $1132.08 \pm 41.78$ & $0.91 \pm 0.02$ \\
\hline \multicolumn{2}{|l|}{ Female } & $2000.00 \pm 85.47$ & $188.08 \pm 10.76$ & $1108.81 \pm 44.88$ & $0.89 \pm 0.02$ \\
\hline \multicolumn{2}{|c|}{ Interaction effect $(\mathrm{N} \times \mathrm{B})$} & ns & ns & ns & ns \\
\hline \multirow{2}{*}{ Summer } & Male & $2050.00 \pm 116.48$ & $197.86 \pm 15.23$ & $1140.54 \pm 63.59$ & $0.90 \pm 0.02$ \\
\hline & Female & $2110.00 \pm 137.81$ & $190.00 \pm 18.02$ & $1116.46 \pm 75.24$ & $0.89 \pm 0.03$ \\
\hline \multirow{2}{*}{ Winter } & Male & $1893.75 \pm 108.95$ & $192.38 \pm 14.25$ & $1124.68 \pm 59.49$ & $0.92 \pm 0.02$ \\
\hline & Female & $1931.25 \pm 108.95$ & $186.88 \pm 14.25$ & $1104.02 \pm 59.49$ & $0.89 \pm 0.02$ \\
\hline
\end{tabular}

ns: non-significance

Means in the same column of group having different superscripts are significantly different $(\mathrm{P}<0.05)$.

Table 9: Least square means \pm standard error of fur mechanical and chemical properties for New Zealand White (NZW) as affected by season, sex and their interaction.

\begin{tabular}{|c|c|c|c|c|c|c|c|}
\hline \multirow{2}{*}{\multicolumn{2}{|c|}{ Parameter }} & \multicolumn{3}{|c|}{ Mechanical properties } & \multicolumn{3}{|c|}{ Chemical properties } \\
\hline & & $\begin{array}{l}\text { Tensile strength } \\
\qquad\left(\mathrm{kg} / \mathrm{cm}^{2}\right)\end{array}$ & $\begin{array}{c}\text { Tearing strength } \\
(\mathrm{kg} / \mathrm{cm})\end{array}$ & $\begin{array}{c}\text { Elongation } \\
(\%)\end{array}$ & $\begin{array}{c}\text { Moisture } \\
(\%)\end{array}$ & $\begin{array}{l}\mathrm{Cr} \\
(\%)\end{array}$ & $\begin{array}{c}\mathrm{pH} \\
(\mathrm{mmol} / \mathrm{L})\end{array}$ \\
\hline \multicolumn{2}{|c|}{ Season effect $(\mathrm{N})$} & ns & $* *$ & $\mathrm{~ns}$ & ns & ns & ns \\
\hline \multicolumn{2}{|l|}{ Summer } & $134.08 \pm 3.28$ & $25.93 \pm 1.24$ & $43.95 \pm 1.54$ & $13.80 \pm 0.09$ & $2.91 \pm 0.04$ & $3.95 \pm 0.04$ \\
\hline \multicolumn{2}{|l|}{ Winter } & $138.21 \pm 2.84$ & $21.29 \pm 1.07$ & $44.16 \pm 1.33$ & $13.72 \pm 0.08$ & $2.87 \pm 0.04$ & $3.95 \pm 0.03$ \\
\hline \multicolumn{2}{|c|}{ Sex effect (B) } & $*$ & ns & $*$ & ns & ns & ns \\
\hline \multicolumn{2}{|l|}{ Male } & $141.07 \pm 2.67$ & $23.73 \pm 1.26$ & $45.86 \pm 1.28$ & $13.79 \pm 0.08$ & $2.88 \pm 0.04$ & $3.95 \pm 0.03$ \\
\hline \multicolumn{2}{|l|}{ Female } & $131.09 \pm 2.87$ & $22.76 \pm 1.35$ & $42.01 \pm 1.37$ & $13.72 \pm 0.09$ & $2.88 \pm 0.04$ & $3.95 \pm 0.03$ \\
\hline \multicolumn{2}{|c|}{ Interaction effect $(\mathrm{N} \times \mathrm{B})$} & $\mathrm{ns}$ & $\mathrm{ns}$ & ns & ns & ns & ns \\
\hline \multirow{2}{*}{ Summer } & Male & $139.19 \pm 3.93^{\mathrm{ab}}$ & $26.54 \pm 1.67$ & $45.26 \pm 1.94$ & $13.84 \pm 0.12$ & $2.93 \pm 0.06$ & $3.94 \pm 0.05$ \\
\hline & Female & $126.93 \pm 4.65^{b}$ & $25.07 \pm 1.98$ & $42.13 \pm 2.29$ & $13.75 \pm 0.14$ & $2.87 \pm 0.07$ & $3.96 \pm 0.06$ \\
\hline \multirow{2}{*}{ Winter } & Male & $142.72 \pm 3.67^{\mathrm{a}}$ & $21.27 \pm 1.56$ & $46.39 \pm 1.81$ & $13.74 \pm 0.11$ & $2.84 \pm 0.06$ & $3.96 \pm 0.05$ \\
\hline & Female & $133.70 \pm 3.67^{\mathrm{ab}}$ & $21.31 \pm 1.56$ & $41.93 \pm 1.81$ & $13.71 \pm 0.11$ & $2.89 \pm 0.06$ & $3.95 \pm 0.05$ \\
\hline
\end{tabular}

ns: non-significance, $* \mathrm{P}<0.05, * * \mathrm{P}<0.01$

Means in the same row of group having different superscripts are significantly different $(\mathrm{P}<0.05)$.

Based on the thicknesses of skin layers (Figure 2 and Table 4), the reason for improvement the mechanical properties of males and winter skins may due to the positive relation between the durability of tanned furs and the thickness of dermis layer especially reticular layer which contains ISSN: 2456-1878

https://dx.doi.org/10.22161/ijeab.53.1 mostly for the bundles of collagen fibers as reported in literatures $[6,21]$.

Although the skins of NZW rabbits were reported in a previous study as not suitable for fur industry since their 
dermis are thick and connective tissue fibers are loose [15], the possibility of using rabbits tanned furs which included NZW breed in leather manufacturing purposes were pointed out in our previous study [6].

Regardless of agreement or disagreement with the obtained results of this study, when comparing the values of the mechanical properties by the acceptable range for different leather manufacturing uses [28], it was found that the tanned furs of NZW rabbits from all experimental groups tended to be little low for leather garment manufacture purpose. Consequently, for improving the durability of rabbits' furs to be suitable for leather manufacturing, it recommended reinforcing it with textile padding.

Arguably based on all aforementioned data, the quality of NZW tanned furs is negatively affected by the improvement of their hair fiber characteristics [29].

Both of summer and females skins, unlike winter and males skins, had the thicker papillary layer $v$ s. reticular layer to accommodate the increment of the follicle activity. Thus, the skins' follicles of the summer season and the females were denser and smaller which produced finer fibers with lower homogeneity than those of the corresponding winter and males ones, respectively. Consequently, summer and females tanned furs were the lower quality due to the decrement in reticular layer thickness and increment of follicle density.

\section{CONCLUSION}

From the applied and industrial point of view, although the variations in the skin characteristics and tanned fur properties, due to season and sex, were detected in the current study, the diameters of most hair fibers are lower than $30 \mu \mathrm{m}$ and thus their furs are suitable for using without causing irritation to humans when worn next to the skin. Additionally, tanned furs of New Zealand rabbits could be using in garment leather manufacturing after reinforcing with textile padding.

\section{ACKNOWLEDGEMENTS}

Authors would like to thank Prof. Samia Hekal, head of Wool Production and Technology Department, Desert Research Centre, Egypt for help and support in the practical part of this study.

\section{REFERENCES}

[1] Taha, E.A., Hekal, S.A. and Badawey, N.S. (2016). Studies of some skin and its coat characteristics in relation to feed additives of growing rabbits. Egyptian J. of rabbit Sci., 26(1): 105-119.

[2] Oznurlu, Y., Celik, I., Sur, E., Telatar, T. and Ozparlak, H. (2009). Comparative skin histology of the White New Zealand and Angora rabbits; Histometrical and Immunohistochemical evaluations. J. Anim. Vet. Adv., 8: 1694-1701.

[3] FAO (2018). Statistical Yearbook, World Food and Agriculture Organization, Rome.

[4] Galal, E.S.E. and Khalil, M.H. (1994). Development of rabbits industry in Egypt. CHEAM-Options Mediterraneans, 43-53.

[5] Lebas, F., Coudert, P., de Rochambeau, H. and Thebault, R.G. (1997). The rabbit husbandry, health and production. FAO, Rome, Italy.

[6] Taha, E.A., Hekal S.A. and Nasr, A.I. (2017). Evaluating skin quality of some rabbit breeds under Egyptian conditions. World Rabbit Sci. 25: 193-200.

[7] Rogers, A.D., Lupton, C.J. and Lukefahr, S.D. (2006). Fibre production and properties in genetically furred and furless rabbits. J. Aim. Sci., 84: 2566-2574.

[8] Tao, Y.R. (1994). Studies on the quality of Rex rabbit fur. World Rabbit Sci., 2:21-24.

[9] Lupton, C.J. (1995). Standard deviation of fiber diameter and other characteristics of United States wool. Sheep and Goat Res. J. 11(3): 111-121.

[10] Barker, J.R. (1958). Principle of biological technique. London, Meunchen, New York. John Wiley. Bancroft, J.D.

[11] El-Ganaieny, M. M. and Abdou, A.S.A. (1999). A histological study on skin hair follicles of Baladi goats. Minufiya J. Agric. Res., 24: 469-480.

[12] Chapman, D.M. (1975). Dichromation of bromophenol blue, with an improvement in the mercuric bromophenol blue technique for protein. Stain Tech., 50: 25-30.

[13] ASTM (2014). American Society for Testing and Materials. Books of standards vol. 15.04.

[14] SAS (2008). SAS/STAT User's Guide (Release 9.2). SAS Inst. Inc., Cary NC, USA.

[15] Yagci, A., Zik, B., Uguz, C. and Altunbas, K. (2006). Histology and morphology of white New Zealand rabbit skin. Indian Vet. J., 83 (8): 876-880.

[16] Nasr A.I., Taha E.A., Naglaa S.B., Essa D.G. (2020). Seasonal variations in furs of Gabaly and New Zealand white rabbits and their crossbred under Egyptian semi-arid conditions. World Rabbit Science, 28: 49-57. https://doi.org/ 10.4995/wrs.2020.12779

[17] Moore, G.P.M., Jackson, N., Isaacs, K. and Brown, G. (1998). Pattern and morphogenesis in skin. J. Theor. Biol., 191:87-94

[18] Thébault R.G., Vrillon J.L. (1994). Seasonal effects on Angora rabbit production. In Hormonal Control of Fibre Growth and Shedding. European Fine Fibre Network Occasional Publication No. 2, pp. 51-60. Laker, JP and Allain, D, eds. Aberdeen: Macaulay Land Use Research Institute.

[19] Rafat S.A, de Rochambeau H., Brims M., Thébault R.G, Deretz S., Bonnet M., Allain D. (2007). Characteristics of 
Angora rabbit fiber using optical fiber diameter analyzer. J. Anim. Sci. 85: 3116-3122. https://doi.org/10.2527/jas.20070109.

[20] Dutta, S. (2008). An Introduction to the Principles of Leather Manufacture ( $\left.4^{\text {ed }}.\right)$ India: Indian Leather Techno Association.

[21] Covington, A.D. (2009). Tanning chemistry the science of leather. RSC publishing, Cambridge, London.

[22] Montagna, W. (1956). The structure and function of skin. New York; Academic Press.

[23] Chapman, R.E. and Ward, K.A. (1979). In "Histological and Biochemical Features of the Wool Fibre and Follicle". Black, J.L. and Reis, P.J. (eds.). Physiological and Environmental Limitations to Wool Growth. University of New England, Armidal, Australia, p. 193-208.

[24] Matter, F.E., M.M. El-Ganaieny, N.A. Shawky and A.S. Abdou (1998). Seasonal variations and wool follicles of Barki sheep raised under desert conditions in Egypt. Desert Institute Bulletin, Egypt, 48 (2): 385-407.

[25] Parmar, M.L., R.D. Sinha, G. Parasad, and Prasad, J. (1988). Histochemical studies on hair follicles and sebaceous and sweet gland in goat. Indian J. Anim. Sci., 58:789-791.

[26] Thorburn G. D., Casey H.B., Molyneux G. S. (1966). Distribution of blood flow within the skin of the rabbit with particular reference to hair growth. Circulation Res., 18: 650-659. https://doi.org/10.1161/01.RES.18.6.650

[27] Stenn K.S., Paus R. (2001). Controls of hair follicle cycling. Physiol. Rev., 81: 450-481. https://doi.org/10.1152/physrev.2001.81.1.449.

[28] BASF. (2007). Pocket book for leather technologist. (4 ed.). 67056 Ludwigshafen, Germany: Badische Anilin- und SodaFabrik.

[29] Jackson-Mass, C.A. and Snyman, M.A. (2000). A comparison of the leather produced from the skin of ten different South Africa sheep breeds. South African J. Anim. Sci., 30: 129-130 